Bond University

Research Repository

\title{
Effect of airway clearance techniques in patients experiencing an acute exacerbation of bronchiectasis: a systematic review
}

Phillips, Jennifer; Lee, Annemarie; Pope, Rodney; Hing, Wayne

Published in:

Physiotherapy Theory and Practice

DOI:

10.1080/09593985.2019.1579286

Licence:

Other

Link to output in Bond University research repository.

Recommended citation(APA):

Phillips, J., Lee, A., Pope, R., \& Hing, W. (2020). Effect of airway clearance techniques in patients experiencing an acute exacerbation of bronchiectasis: a systematic review. Physiotherapy Theory and Practice, 36(12), 13001315. https://doi.org/10.1080/09593985.2019.1579286

\section{General rights}

Copyright and moral rights for the publications made accessible in the public portal are retained by the authors and/or other copyright owners and it is a condition of accessing publications that users recognise and abide by the legal requirements associated with these rights.

For more information, or if you believe that this document breaches copyright, please contact the Bond University research repository coordinator. 


\section{Effect of airway clearance techniques in patients experiencing an}

\section{acute exacerbation of bronchiectasis: A systematic review}

\section{Authors:}

Jennifer Phillips BPhty (Hons) (Faculty of Health Sciences and Medicine, Bond University,

2 Promethean Way, Robina QLD 4226, Australia; The Wesley Hospital, Uniting Care Health 451 Coronation Drive, Auchenflower QLD 4066, Australia).

Annemarie Lee BPhty, MPhysio, PhD, (Department of Physiotherapy, School of Primary and Allied Health Care, Monash University, McMahons Road, Peninsula, VIC 3199 Australia; Institute for Breathing and Sleep, Austin Health, 145 Studley Road, Heidelberg VIC 3084, Australia)

Rodney Pope BAppSc(Phty), PhD (School of Community Health, Charles Sturt University, PO Box 789 Albury NSW 2640, Australia).

Wayne Hing BPhty, PhD (Faculty of Health Sciences and Medicine, Bond University, 2 Promethean Way, Robina QLD 4226, Australia)

Corresponding Author:Jennifer Phillips. Faculty of Health Sciences and Medicine, Bond University: 2 Promethean Way, Robina QLD 4226, Australia. Email: jphillip@,bond.edu.au

Key words Bronchiectasis; exacerbation; airway clearance; mucociliary clearance; chest physiotherapy

This is an Accepted Manuscript of an article published by Taylor \& Francis in Physiotherapy Theory and Practice online on 18/2/2019, available online: 


\section{ABSTRACT}

Background: Airway clearance techniques (ACTs) are recommended for people with bronchiectasis both in stable state and during an acute exacerbation. Research has previously investigated ACTs for individuals in a stable state, but the safety and efficacy of ACTs during an acute exacerbation has not been reviewed.

Methods: A systematic review was completed of studies of ACTs undertaken in adults and children experiencing an acute exacerbation of bronchiectasis. The databases Pubmed, Embase, PEDro and CINAHL were searched. Methodological quality of studies was examined using the modified Downs and Black tool. Key findings were synthesised using a critical narrative approach.

Results: Six studies were included with a total of 120 participants. No eligible studies involving child participants were found. Overall, the methodological quality of studies was moderate. All ACTs investigated appeared safe for adults, with no adverse reactions reported. The active cycle of breathing technique may be more effective at improving gas exchange, sputum volume and health-related quality of life compared to postural drainage and percussion. Participants in two studies preferred oscillating positive expiratory pressure devices over the active cycle of breathing or postural drainage techniques.

Conclusions: All airway clearance techniques reported in this review appeared safe for adults experiencing an acute exacerbation of bronchiectasis. 


\section{INTRODUCTION}

Bronchiectasis is a chronic and progressive lung condition which decreases health-related quality of life (HRQoL) (Barker, 2002; Mutalithas et al, 2008). Symptomatically, individuals have a chronic cough, sputum production, shortness of breath and decreased exercise tolerance (Goeminne and Dupont, 2010). Individuals suffer from recurrent lung infections which cause bronchial inflammation and permanent dilation, abnormal sputum clearance and bacterial colonisations which lead in turn to further infection (Barker, 2002; Flume, Chalmers, and Oliver, 2018; Goeminne and Dupont, 2010). Recurrent exacerbations lead to progressive deterioration of lung function and are one of the strongest predictors of morbidity, mortality and decreased HRQoL in bronchiectasis (Elborn and Bell, 2007; McShane, Naureckas, Tino, and Strek, 2013).

An exacerbation of bronchiectasis is diagnosed when a clinician determines a change in bronchiectasis treatment is required as well as a deterioration in three or more of the following symptoms for at least forty-eight hours: cough; sputum volume and/or consistency; sputum purulence; haemoptysis, breathlessness and/or exercise tolerance; fatigue and/or malaise (Hill et al, 2017). The presentation of bronchiectasis, especially during an acute exacerbation, supports the prescription of airway clearance techniques (ACTs) as part of management alongside medical treatment such as oral or intravenous antibiotics and steroids (Chang et al, 2015; Pasteur, Bilton, Hill, and Group, 2010; Polverino et al, 2017). National and international guidelines recommend that physiotherapists should prescribe ACTs to individuals when experiencing an exacerbation and when stable (Chang et al, 2015; Pasteur et al, 2010; Polverino et al, 2017). It has been stated that ACTs are especially important during an exacerbation to clear the increased sputum load (Patterson et al, 2007). Airway clearance techniques may include breathing exercises such as the active cycle of breathing technique 
(ACBT) and autogenic drainage, positioning and postural drainage (PD), manual techniques such as percussion or vibration, or techniques requiring a device such as positive expiratory pressure (PEP) therapy and oscillating PEP therapy (Snijders et al, 2015; van der Schans, 2007).

Previous reviews and research have focused on the use of ACTs during the stable clinical state of bronchiectasis, showing that various techniques such as PEP therapy, oscillating PEP therapy, PD, expiration with glottis open in lateral position (ETGOL) and high frequency chest wall oscillation are safe and effective at increasing sputum production compared to no intervention (Lee, Burge, and Holland, 2015; Lee, Williamson, Lorensini, and Spencer, 2015; Muñoz, Gracia, Buxó, Alvarez, and Vendrell, 2018). However, there is very limited evidence regarding the effectiveness of ACTs during an acute exacerbation of bronchiectasis that is not associated with cystic fibrosis. In the one previous review which included individuals experiencing an acute exacerbation as well as those in a stable state, the results did not separately analyse the findings based on clinical state and so the authors could only conclude that ACTs were safe for individuals during the stable state of their disease (Snijders et al, 2015). There have been no systematic reviews investigating ACTs exclusively in individuals experiencing an acute exacerbation.

The primary aim of this systematic review was therefore to establish if ACTs are safe for individuals experiencing an acute exacerbation of bronchiectasis not associated with cystic fibrosis. The secondary aim was to establish the effectiveness of ACTs in improving outcomes including sputum clearance, lung function, arterial blood gases, quality of life and breathlessness for these individuals. The protocol for this systematic review was registered with PROSPERO (PROSPERO 2016 CRD42016053306). 


\section{METHOD}

Guidance provided by the PRISMA statement for systematic reviews was followed for this systematic review (Moher, Liberati, Tetzlaff, Altman, and Group, 2009). Prior to conducting this review, the Cochrane Library, Physiotherapy Evidence Database (PEDro) and the PROSPERO database were searched to ensure a similar systematic review or protocol had not been published.

\section{$\underline{\text { Eligibility criteria }}$}

Studies were eligible for inclusion if they included adults or children with a medical diagnosis of bronchiectasis not associated with cystic fibrosis (confirmed by HRCT scan, bronchography or physician) who were experiencing an acute exacerbation and who were prescribed ACT(s). Studies were excluded if they were not available in English or were published as abstract only, if they used a case study design or if interventions were completed without the goal of sputum clearance (e.g. mobility to increase exercise tolerance). Studies which involved multi-pronged interventions where the effects of each component could not be disentangled and studies which included individuals with a respiratory condition other than bronchiectasis were also excluded.

\section{Search strategy}

One investigator conducted the database search to identify studies that might be eligible for inclusion in the review. Electronic databases of Pubmed, Embase, PEDro and CINAHL were searched, as well as the grey literature database World Cat. Similar key words were used to search each database and included "bronchiectasis" AND "airway clearance techniques" OR "chest physiotherapy" OR "mucociliary clearance" OR "bronchopulmonary hygiene". Relevant synonyms of each term were also employed, as well as MeSH or other standardised terms used in each database. An example of the search strategy applied in PubMed and 
adapted for other databases is included in Appendix 1. A manual search of the reference lists of included papers was also completed to identify any other studies of potential relevance. The search was completed in January 2018. No date, language or other filters were applied during the search.

\section{$\underline{\text { Study selection }}$}

Two reviewers screened titles and abstracts of all articles identified in the search to exclude duplicates and all of those that were clearly ineligible. The full text of remaining articles was then reviewed by the same two reviewers, to assess eligibility for inclusion. A third reviewer was consulted if consensus could not be reached. Results of the search, screening and selection processes were documented in a PRISMA flow diagram (Moher et al, 2009).

\section{Quality assessment}

To assess the methodological quality of included articles, a modified Downs and Black critical appraisal tool (Downs and Black, 1998 ) was applied independently to each included article by two reviewers (JP and AL). The Downs and Black tool is a widely used, reliable and valid tool used to assess the methodological quality of both randomised and nonrandomised studies and contains items that assess methodological issues that may affect both internal and external validity. The original version of this tool has 27 questions that together score studies out of a total 32 points, as question 5 is scored on a 0 -2-point scale and question 27 on a 0-5 point scale. A modified version was used for this review, which scored both question 5 and question 27 dichotomously. Question 5 scored 1 if a list of principal confounders was reported and 0 if not, and question 27 scored 1 if a power or sample size calculation was attempted or reported and 0 if not. This modification has been used previously (Ng, Mackney, Jenkins, and Hill, 2012). 
The quality of each included article was then rated using a scale from poor to strong quality, dependent on the total score. A percentage was calculated from the potential score out of 27 . Articles were considered poor quality if scored $<25 \%$, limited quality if scored $25-49 \%$, moderate quality if scored $50-74 \%$ and strong quality if scored $>75 \%$ (Jäkel and von Hauenschild, 2011). No articles were excluded based on the quality assessment, but methodological quality of specific studies was considered during data synthesis and analysis.

\section{Data Extraction}

A standardised, pre-piloted form was used to extract data from each included study, including participant demographics, study setting, study methodology, interventions, outcome measures and timing of outcome measures. Missing data were requested from authors, where required, and extracted data were tabulated. If a paper also included participants with conditions other than an acute exacerbation of bronchiectasis not related to cystic fibrosis, only the participants experiencing an acute exacerbation of bronchiectasis were used in analysis for this review.

\section{Synthesis and outcomes}

A critical narrative approach was employed in the synthesis of key findings from included studies and was structured around the types of interventions investigated, target population characteristics, types of outcomes assessed and key findings. Criteria used to assess safety, acceptability and effectiveness of ACTs (clinical outcomes) are listed in Table 1

(Venkategowda et al, 2014). Meta-analysis was not conducted due to the heterogeneity in study designs, intervention types and durations, and outcome measures employed. 


\section{$\underline{\text { RESULTS }}$}

The results from the search strategy and screening process can be seen in the PRISMA diagram in Figure 1. The search strategy yielded 3075 articles, of which 1085 were duplicates and excluded. A total of 1990 articles were screened by title and abstract and 54 remaining articles were screened in full text. There were six studies that met the eligibility criteria (Table 2).

\section{Quality assessment}

The final methodological quality scores assigned to each article by both reviewers can be seen in Table 3. There was excellent agreement between reviewers for the modified Downs and Black scores (98\%, Kappa 0.95). The mean final score for the six studies was 18/27 (range 14 -24) (Table 3). Two studies were considered to be of strong methodological quality, and four of moderate quality. The overall mean score for all six studies represents a moderate methodological quality score. Most studies scored well for reporting and internal validity bias domains, and poorly for the external validity and confounding bias domains.

\section{$\underline{\text { Participants }}$}

A total of 120 participants with an acute exacerbation of bronchiectasis were included in these six studies, of whom $62(52 \%)$ were males (Table 2). Sample sizes ranged from two to 30 participants, and all were adults. No studies were found that investigated children. Five of the six studies were completed in an inpatient setting, and one in an outpatient department.

Table 2 provides further details of participant characteristics.

\section{$\underline{\text { Interventions }}$}

Across the six included studies there were a range of interventions employed for airway clearance. Five studies compared the effects of two different techniques, and one study 
investigated the impact of three different techniques. Overall, nine different techniques were included across the six studies; ACBT, PD +/- percussion, PEP devices, temporary positive expiratory pressure (TPEP), autogenic drainage, thoracic compression, oscillating PEP (using the Flutter ${ }^{\circledR}$ valve or Acapella ${ }^{\circledR}$ devices), and deep breathing exercises. Further details can be found in Table 2.

Duration of the study periods across which ACT were administered to the participants varied greatly between studies, from one study including a single treatment session of each ACT (Herala and Gislason, 1988), to another study where the intervention was completed daily from hospital admission through to discharge (10 - 60 days) (D'Abrosca et al, 2017). The majority of studies ran for 6 to 14 days, which was the period of hospital admission or of antibiotic therapy.

Prescription of ACTs each day and supervision of techniques being performed also varied amongst studies. One study completed in an outpatient setting had a physiotherapist teach an ACT (Acapella ${ }^{\circledR}$ ) to participants on a single occasion at the start of an exacerbation, and then the participants were asked to complete it independently at home for the remainder of the study period (Patterson et al, 2007). Most participants in that study reported completing their prescribed ACT twice daily. The other five studies were implemented in an inpatient setting, where the ACT was supervised or performed (depending on the type of ACT) by a physiotherapist on each occasion. One study prescribed ACTs to be completed three times per day (Tsang and Jones, 2003), while two involved ACTs completed twice daily for the study period (AbdelHalim, AboElNaga, and Fathy, 2016; D'Abrosca et al, 2017). One study did not report how many times per day ACT were completed (Grillo et al, 2015), and the final study involved a single treatment session (Herala and Gislason, 1988). Table 2 provides further details. 


\section{$\underline{\text { Safety }}$}

All six studies reported nil adverse events throughout their treatment routines (AbdelHalim et al, 2016; D'Abrosca et al, 2017; Grillo et al, 2015; Herala and Gislason, 1988; Patterson et al, 2007; Tsang and Jones, 2003). However, one study did report some participants experienced occasional dizziness with PEP and TPEP due to hyperventilation (D'Abrosca et al, 2017). The authors did not report the number or percentage of participants that reported this side effect and the authors did not consider this an adverse event.

In addition, the within-groups changes in clinical outcome measures reported in Table 4 indicate that there were no instances where clinical or other patient outcomes were observed to significantly deteriorate over the course of treatment, with any of the treatment techniques. On this basis, there is no evidence from any of the included studies to indicate that any of the observed ACTs resulted in any harm to participants who were experiencing an acute exacerbation of bronchiectasis.

\section{Acceptability of technique}

Two studies examined acceptability to the participant of oscillating PEP (one using Acapella ${ }^{\circledR}$ device and the other using Flutter ${ }^{\circledR}$ device) and compared this to acceptability of "usual airway clearance" (90\% ACBT, 10\% PEP) or breathing and coughing in upright sitting or a PD position (Patterson et a., 2007; Tsang and Jones, 2003). Both showed participant preference towards oscillating PEP. The first study reported 7 of 10 participants preferred Acapella ${ }^{\circledR}$ to their "usual airway clearance technique" (majority using ACBT) and those participants chose to continue Acapella ${ }^{\circledR}$ as their ACT when reassessed one month following study cessation (Patterson et al, 2007). In the other study, Flutter ${ }^{\circledR}$ was consistently perceived to be more effective than breathing and coughing in upright sitting or a PD position, when effectiveness was measured by a subjective 4-point Likert scale ranging from "not effective 
at all" to "very effective", on day 2 and day 4 of hospital admission and on day of discharge, following an acute exacerbation (overall mean $\mathrm{p}=0.011)$ (Tsang and Jones, 2003).

\section{Clinical Outcomes}

There were a variety of clinical and other patient outcomes assessed in participants with an acute exacerbation of bronchiectasis, including lung function, sputum clearance, arterial blood gases, quality of life and breathlessness. The key outcomes are presented below and further details are provided in Table 4.

\section{Sputum clearance}

Three studies reported the effects of ACTs on sputum clearance (AbdelHalim et al, 2016; Patterson et al, 2007; Tsang and Jones, 2003). The method by which sputum production or expectoration was measured varied through the studies, but most studies reported an improvement in sputum clearance following use of an ACT. Two studies implemented the ACBT and found improvements in sputum expectoration (wet weight or volume) over the course of an exacerbation (AbdelHalim et al, 2016; Patterson et al, 2007). Within one of those studies, the ACBT in a PD position was found to be superior to percussion in a PD position when completed twice per day over the course of 14 days and when the wet weight of sputum produced was measured at the beginning of an exacerbation and again on day 14 (AbdelHalim et al, 2016). In the other study, use of the Acapella ${ }^{\circledR}$ was associated with a greater volume of sputum production in a single treatment session than "usual airway clearance technique" (90\% ACBT, 10\% PEP), but this difference did not reach statistical significance (Patterson et al, 2007). Both that study and one other found that oscillating PEP (Acapella ${ }^{\circledR}$ device or Flutter ${ }^{\circledR}$ device) improved sputum production when compared to "usual airway clearance therapy" (ACBT 90\%, PEP 10\%) or PD with breathing and coughing, but 
this difference did not reach statistical significance (Patterson et al, 2007; Tsang and Jones, 2003).

\section{Lung function}

Four of the six studies incorporated lung function tests using spirometry (forced expiratory volume in 1 second $\left(\mathrm{FEV}_{1}\right)$, forced vital capacity $(\mathrm{FVC})$, maximal mid-expiratory flow (MMEF), vital capacity (VC), peak expiratory flow (PEF)), pre and post an ACT (AbdelHalim et al., 2016; D'Abrosca et al., 2017; Patterson et al., 2007; Tsang and Jones, 2003). In most studies, participants demonstrated a small but non-significant improvement in their lung function tests when the tests were administered at the beginning of an exacerbation and repeated following intervention or at the time of hospital discharge or cessation of antibiotics. However, none of the studies indicated that any given ACT was more effective than any other for improving lung function.

Only one study found a small significant change in lung function test results when the tests were completed at the beginning of an exacerbation and again at cessation of antibiotic treatment which lasted 14 days. AbdelHalim et al. (2016) showed a significant improvement in FVC and MMEF following ACBT combined with PD administered twice daily for 14 days. The same study also showed significant improvement in FEV 1 and MMEF following percussion and PD completed twice per day for 14 days. However, despite these within-group improvements, there was no difference between the ACBT and percussion group in observed improvements (Table 4).

Two studies conducted lung function testing before and after individual treatment sessions during the study period. One of these studies, comparing Acapella ${ }^{\circledR}$ to "usual airway clearance therapy" (ACBT 90\%, PEP therapy 10\%), found no changes in lung function after a single treatment session at the start or end of a course of oral antibiotics in either group, nor 
a difference between groups in post-treatment lung function on either occasion (Patterson et al, 2007). The other study found similar results when comparing Flutter ${ }^{\mathbb{R}}$ valve, PD with breathing and coughing, and breathing and coughing in upright sitting, with no changes in lung function observed following treatment on day 2, day 4 or day of discharge within each ACT group (Tsang and Jones, 2003). Furthermore, no differences in lung function were observed between groups following treatment on any of those days (Tsang and Jones, 2003).

\section{$\underline{\text { Arterial blood gases and pulse oximetry }}$}

Gas exchange measured by components of arterial blood gases (ABGs) was assessed as an outcome measure in two studies. AbdelHalim et al. (2016) showed gas exchange improved significantly following a course of treatment in hospital involving either ACBT with PD or percussion with PD. Following ACBT with $\mathrm{PD}, \mathrm{PaO}_{2}$ and $\mathrm{PAO}_{2}$ both significantly improved, while following percussion with $\mathrm{PD}, \mathrm{PaCO}_{2}, \mathrm{PaO}_{2}$ and $\mathrm{PAO}_{2}$ all improved significantly when compared to baseline. However, ACBT with PD was associated with superior improvement in $\mathrm{PaO}_{2}$ and in the $\mathrm{P}(\mathrm{A}-\mathrm{a}) \mathrm{O}_{2}$ gradient when compared to percussion with $\mathrm{PD}$. Another study found no difference in the changes in ABG results observed following use of TPEP and PEP (D'Abrosca et al, 2017).

Pulse oximetry was measured in two studies, one during each treatment session and the other at the beginning and cessation of the study (Patterson et al, 2007; Tsang and Jones, 2003). Tsang and Jones (2003) reported no significant change in readings during treatment sessions involving Flutter ${ }^{\circledR}$ valve, PD with breathing and coughing, or breathing and coughing in upright sitting. The second study, which compared the observed changes in pulse oximetry readings following Acapella ${ }^{\circledR}$ to those following their "usual airway clearance therapy" (ACBT 90\%, PEP 10\%) reported no significant changes in either group from the beginning to the end of a course of oral antibiotics (Patterson et al, 2007). 
One study measured blood gases using a transcutaneous electrode attached to the upper anterior chest during PEP therapy and thoracic compression (manual compression of the chest wall at end exhalation) (Herala and Gislason, 1988). Individual participant results were reported and two participants with an exacerbation of bronchiectasis were included in the study. Both participants experienced a small $(0.1$ and $1.5 \mathrm{kPa})$ increase in transcutaneous pressure of oxygen with thoracic compression lasting 5 minutes or less. One participant experienced a small decrease in oxygen pressure with PEP therapy $(-0.6 \mathrm{kPa})$ lasting 5 minutes, whilst the other had an improvement of oxygen pressure with PEP therapy of $1.0 \mathrm{kPa}$ (Herala and Gislason, 1988). Both participants experienced a minimal decrease in the reported transcutaneous pressure of $\mathrm{CO}_{2}$ with both thoracic compression and PEP therapy, which lasted longer following thoracic compression compared to PEP therapy.

\section{Quality of Life, breathlessness and symptoms}

Only one study assessed quality of life, and they used the Leister Cough Questionnaire (AbdelHalim et al, 2016). This study found that although both groups showed improvement across the study period, ACBT with PD was superior to percussion with PD for improving cough-related quality of life over 14 days of treatment $(p=0.019)$.

Two studies investigated breathlessness, using different outcome measures. One study used the BORG scale and the other the modified Medical Research Council (mMRC) scale. In one of these studies, breathlessness, as measured by the mMRC scale, was observed to significantly improve from beginning to end of hospital admission, which incorporated using either the ACBT with PD or percussion with PD $(\mathrm{p}<0.001$ and $\mathrm{p}<0.001$ respectively) (AbdelHalim et al, 2016). However, there was no significant difference between these techniques in the levels of improvement in breathlessness observed following their use (AbdelHalim et al, 2016). In the other study, which used the BORG breathlessness scale pre 
and post intervention (on day 1 and on final day of oral antibiotics), no significant changes were observed in any of these measures (Patterson et al, 2007). This indicated that neither Acapella ${ }^{\circledR}$ nor “usual airway clearance therapy" (ACBT 90\%, PEP 10\%) changed patients' perceived breathlessness in a single treatment session (Patterson et al, 2007).

Only one study measured patient reported symptoms. Patterson et al. (2007) recorded patient's respiratory symptoms across the course of an exacerbation, comparing symptoms in those using Acapella ${ }^{\circledR}$ with symptoms in those using "usual airway clearance therapy" (ACBT 90\%, PEP 10\%). Although participants within each treatment group improved following treatment on measures including sputum volume and colour, intensity and frequency of cough, fatigue, exercise tolerance, sinus discharge and appetite, there were no differences between the Acapella ${ }^{\circledR}$ and "usual airway clearance therapy" groups in observed improvements.

\section{Lung Clearance Index}

The lung clearance index was reported as an outcome in one study (Grillo et al, 2015). The lung clearance index was completed pre and post physiotherapy (ACBT with or without PD or autogenic drainage) at the start and end of an exacerbation (day of discharge). There was no significant difference on either occasion following physiotherapy (Grillo et al, 2015).

\section{$\underline{\text { DISCUSSION }}$}

This is the first systematic review to have investigated ACTs exclusively in participants experiencing an acute exacerbation of bronchiectasis not associated with cystic fibrosis. It is noteworthy that no studies were found that included child participants; all six included studies involved adult participants experiencing an acute exacerbation. From these studies, a key finding is that a range of ACTs appeared to be safe to implement in adults experiencing 
an acute exacerbation, as no studies reported any significant adverse events and none of the outcome measures reported in the studies deteriorated following use of the ACTs.

Only one study found significant differences between two different types of ACTs. While both ACBT with PD and PD with percussion were associated with improved sputum expectoration, gas exchange and reduced dyspnoea, greater improvements in cough-related QoL, gas exchange and sputum expectoration were noted with ACBT with PD (AbdelHalim et al, 2016). This is similar to results found in other published systematic reviews, which state that ACBT may be superior to percussion and PD in short term sputum expectoration (Lewis, Williams, and Olds, 2012), and that percussion has shown limited effectiveness for sputum expectoration or improving lung function in patients with COPD or bronchiectasis (Holland, 2014; van der Schans, 2007). It may also be because although a "huff" was taught to all participants in the ACBT group, it is unclear if participants in the percussion group were instructed to complete a "huff", which may be one of the most important aspects of any ACT (van der Schans, 2007). These findings suggest that during an acute exacerbation of bronchiectasis, prescribing ACBT combined with percussion may improve sputum clearance, gas exchange and cough related QoL.

While oscillating PEP appeared to show a trend in improved sputum expectoration in two studies, neither of these trends reached statistical significance (Patterson et al, 2007; Tsang and Jones, 2003). This may be due to low numbers of participants in the included studies or the heterogeneity in the control group (90\% ACBT vs 10\% PEP) (Patterson et al., 2007; Tsang and Jones, 2003). The timing of sputum collection was also variable, one study (Tsang and Jones, 2003) measured the sputum collected both during the treatment session and for the following 24 hours, whilst the other only collected sputum during the treatment session (Patterson et al, 2007). Sputum clearance may continue post completion of the ACT and so 
this may be a limiting factor for why significance was not reached in the second study (Patterson et al, 2007). These findings correlate to findings in participants with stable bronchiectasis, where oscillating PEP was shown to be effective at increasing sputum clearance inconsistently amongst included studies (Lee, Williamson, et al, 2015).

Two studies in this review highlighted that patients may prefer an oscillating PEP over ACBT +/- PD and breathing and coughing and felt that it may be more beneficial for sputum expectoration (Patterson et al, 2007; Tsang \& Jones, 2003). It is widely recognised that patient preference and adherence to treatment in bronchiectasis is important (Chalmers, Aliberti, and Blasi, 2015; Pasteur et al, 2010; van der Schans, 2007). This may therefore require further consideration in future studies examining the comparisons of different types of ACTs during an exacerbation. Specifically, well powered studies which investigate oscillating PEP and ACBT during an acute exacerbation of bronchiectasis would be valuable. This is because from the studies conducted to date, these two techniques appear to be the most effective at improving patient outcomes, but from the current research it is unclear which is superior.

A range of ACTs were examined across the six included studies. Within all the included studies, participants consistently demonstrated improvements (where measured) in sputum expectoration, lung function, cough related QoL and gas exchange, from beginning of an acute exacerbation to conclusion of the study. However, all studies applied ACTs within a multifaceted treatment regimen of antibiotics and other medical care. Based on this, the improvements seen from the beginning to the conclusion of each study indicate that while ACTs did not appear to cause a deterioration in a participants' condition, the impact alone of an ACT and the extent of their contribution to observed effects on outcome measures is difficult to establish. 
All included studies involved relatively small numbers of participants; these ranged from two to thirty participants. It is possible that potentially clinically significant findings were not identified due to low participant numbers decreasing the power of the studies. More studies involving larger participant cohorts are required to further develop knowledge in this area. As noted above, no studies were found by this review that investigated ACTs for children experiencing an acute exacerbation of bronchiectasis. There are specific factors that need to be considered prior to implementing ACT for children. These include age, complexity and demands of treatment, level of support, influences upon adherence and preserving family relationships and a child's sense of normality (Lee, Button, and Tannenbaum, 2017). For these reasons, studies involving children are required. More studies with larger sample sizes are also needed to further ensure safety and assess adherence (Lee et al, 2017).

Of the six included studies, two were found to be of strong methodological quality, and four of moderate methodological quality. Only one study made an attempt to blind those measuring the main outcome of the study, and to calculate the required sample size (Patterson et al, 2007). All studies recruited participants from the population of interest (adults experiencing an acute exacerbation of bronchiectasis) and participants in each group were recruited over the same period of time, where more than one group was involved. All studies also used accurate and valid outcome measures. It is common for studies in chronic respiratory disease patient populations to have low or moderate methodological quality, and so finding and including two studies that exhibited "strong" quality is a strength of this review (Jones and Rowe, 2000; Lee, Williamson, et al, 2015; Polverino et al, 2017).

On this basis, further research into the safety and effectiveness of ACTs is required in participants experiencing an acute exacerbation of bronchiectasis, using larger sample sizes and with higher methodological quality. Future research should also consider a range of 
ACTs, particularly those which are safe and effective when applied in people who are in a stable state of bronchiectasis such as PEP therapy and oscillating PEP therapy and ETGOL (Lee, Holland et al, 2015; Muñoz et al, 2018). This research is imperative as ACTs are currently recommended and routinely completed for patients with both stable bronchiectasis and during an acute exacerbation as per recommendations in clinical guidelines (Chalmers et al, 2015; Chang et al, 2015; O'Neill, Bradley, McArdle, and MacMahon, 2002; Pasteur et al, 2010; Polverino et al, 2017)

\section{CONCLUSION}

Airway clearance techniques are routinely recommended by physicians as part of maintenance in patients with bronchiectasis, and guidelines suggest that a change of ACT may be required during an acute exacerbation (Chalmers et al, 2015; Pasteur et al, 2010). All ACTs implemented in the studies included in this review were reported to be well tolerated during an acute exacerbation. However, this review was limited by the small number of studies available and the fact that those included had limited sample sizes and involved only adults, and no children. The ACBT combined with PD was found to be superior in sputum expectoration, cough related quality of life and gas exchange when compared to percussion combined with PD. No other significant differences were observed in any of the included studies between specific ACTs, however oscillating PEP therapy was preferred by participants over other types of ACTs and may be associated with an increase in sputum production. More research is required with larger sample sizes and higher methodological quality, including both children as well as adult participants, to further assess the safety and effectiveness of ACTs in both adults and children experiencing an acute exacerbation of bronchiectasis.

Disclosure of Interest: The authors report no conflict of interest. 


\section{$\underline{\text { References }}$}

AbdelHalim HA, AboElNaga HH, Fathy KA 2016 Comparison between active cycles of breathing with postural drainage versus conventional chest physiotherapy in subjects with bronchiectasis. Egyptian Journal of Chest Diseases and Tuberculosis 65: 157-165.

Barker AF 2002 Bronchiectasis. New England Journal of Medicine 346: 1383-1393.

Chalmers JD, Aliberti S, Blasi F 2015 Management of bronchiectasis in adults. European Respiratory Journal 45: 1446-1462.

Chang AB, Bell SC, Torzillo PJ, Byrnes CA, Maguire, GP, Holland, AE, O'Mara P, Grimwood K, Alison J, Cull C, Currie B, Gardner I, Holmes P, Hunter C, Kolbe J, Maclennan C, McDonald M, Morris P, Nicholson C, Petsky H, Pillarisetti N, Reynolds E, Serisier D, Thein F, van Asperen P, Voss L, Wong C, Extended Voting Group 2015 Thoracic Society of Australia and New Zealand Guidelines: Chronic Suppurative lung disease and bronchiectasis in children and adults in Australia and New Zealand. Medical Journal of Australia 202: 21 - 24.

D'Abrosca F, Garabelli B, Savio G, Barison A, Appendini L, Oliveira LVF, Baiardi P, Balbi B 2017 Comparing airways clearance techniques in chronic obstructive pulmonary disease and bronchiectasis: positive expiratory pressure or temporary positive expiratory pressure? A retrospective study. Brazilian Journal of Physical Therapy 21: 15-23.

Downs SH, Black N 1998 The feasibility of creating a checklist for the assessment of the methodological quality both of randomised and non-randomised studies of health care interventions. Journal of Epidemiology and Community Health 1998: 377-384.

Elborn JS, Bell SC 2007 Pulmonary exacerbations in cystic fibrosis and bronchiectasis. Thorax 62: 288-290.

Flume PA, Chalmers JD, Oliver KN 2018 Advances in bronchiectasis: endotyping, genetics, microbiome, and disease heterogeneity. The Lancet 392: 880-890.

Goeminne P, Dupont L 2010 Non-cystic fibrosis bronchiectasis: diagnosis and management in 21st century. Postgraduate Medical Journal 86: 493-501.

Grillo L, Irving S, Hansell DM, Nair A, Annan B, Ward S, Bilton D, Main E, Davies J, Bush A, Wilson R, Loebinger MR 2015 The reproducibility and responsiveness of the lung clearance index in bronchiectasis. European Respiratory Journal 46: 1645-1653.

Herala M, Gislason T 1988 Chest physiotherapy evaluation by transcutaneous blood gas monitoring. Chest 93: 800-802. 
Hill AT, Haworth CS, Aliberti S, Barker A, Blasi F, Boersma W, Chalmers JD, De Soyza A, Dimakou K, Elborn JS, Feldmen C, Flume P, Goeminne PC, Loebinger MR, Menendez R, Morgan L, Murris M, Polverino E, Quittner A, Ringshausen FC, Tino G, Torres A, Vendrell M, Welte T, Wilson R, Wong C, O'Donnell A, Aksamit T and group 2017 Pulmonary exacerbation in adults with bronchiectasis: a consensus definition for clinical research. European Respiratory Journal 49.

Holland AE 2014 Physiotherapy management of acute exacerbations of chronic obstructive pulmonary disease. Journal of Physiotherapy 60: 181-188.

Jäkel A, von Hauenschild P 2011 Therapeutic Effects of Cranial Osteopathic Manipulative Medicine: A Systematic Review. The Journal of the American Osteopathic Association 111: 685-693.

Jones A, Rowe BH 2000 Bronchopulmonary hygiene physical therapy in bronchiectasis and chronic obstructive pulmonary disease: A systematic review. Heart \& Lung: The Journal of Acute and Critical Care 29: 125-135.

Lee AL, Burge AT, Holland AE 2015 Airway clearance techniques for bronchiectasis. Cochrane Database of Systematic Reviews 11: CD008351.

Lee AL, Button BM, Tannenbaum EL 2017 Airway-Clearance Techniques in Children and Adolescents with Chronic Suppurative Lung Disease and Bronchiectasis. Frontiers in Pediatrics 5: 2.

Lee AL, Williamson HC, Lorensini S, Spencer LM 2015 The effects of oscillating positive expiratory pressure therapy in adults with stable non-cystic fibrosis bronchiectasis: A systematic review. Chronic Respiratory Disease 12: 36-46.

Lewis LK, Williams MT, Olds TS 2012 The active cycle of breathing technique: a systematic review and meta-analysis. Respiratory Medicine 106: 155-172.

McShane PJ, Naureckas ET, Tino G, Strek ME 2013 Non-cystic fibrosis bronchiectasis. American Journal of Respiratory \& Critical Care Medicine 188: 647-656.

Moher D, Liberati A, Tetzlaff J, Altman DG, PRISMA Group 2009 Preferred reporting items for systematic reviews and meta-analyses: the PRISMA statement. Annals of Internal Medicine 151: 264-269

Muñoz G, Gracia J, Buxó M, Alvarez A, Vendrell M 2018 Long-term benefits of airway clearance in bronchiectasis: a randomised placebo-controlled trial. European Respiratory Journal, 51.

Mutalithas K, Watkin G, Willig B, Wardlaw A, Pavord ID, Birring SS 2008 Improvement in health status following bronchopulmonary hygiene physical therapy in patients with bronchiectasis. Respiratory Medicine 102:1140-1144. 
Ng LWC, Mackney J, Jenkins S, Hill K 2012 Does exercise training change physical activity in people with COPD? A systematic review and meta-analysis. Chronic Respiratory Disease 9:17-26.

O'Neill B, Bradley JM, McArdle N, MacMahon J 2002 The current physiotherapy management of patients with bronchiectasis: a UK survey. International Journal of Clinical Practice, 56: 34-35.

Pasteur MC, Bilton D, Hill AT, Group, B. T. S. B. n. C. F. G. (2010). British Thoracic Society guideline for non-CF bronchiectasis. Thorax 65 Suppl 1: i1-58.

Patterson JE, Hewitt O, Kent L, Bradbury I, Elborn JS, Bradley JM 2007 Acapella versus 'usual airway clearance' during acute exacerbation in bronchiectasis: a randomized crossover trial. Chronic Respiratory Disease 4:67-74.

Polverino E, Goeminne PC, McDonnell MJ, Aliberti S, Marshall SE, Loebinger MR, Murris M, Canton R, Torres A, Dimakou K, De Soyza A, Hill AT, Haworth CS, Vendrell M, Ringshausen FC, Subotic D, Wilson R, Vilaro J, Stallberg B, Welte T, Rohde G, Blasi F, Elborn S, Almagro M, Timothy A, Ruddy T, Tonia T, Rigau D, Chalmers JD 2017 European Respiratory Society guidelines for the management of adult bronchiectasis. European Respiratory Journal 50.

Snijders D, Fernandez Dominguez B, Calgaro S, Bertozzi I, Escribano Montaner A, Perilongo G, Barbato A 2015 Mucociliary clearance techniques for treating non-cystic fibrosis bronchiectasis: Is there evidence? International Journal of Immunopathology \& Pharmacology 28:150-159.

Tsang S, Jones A 2003 Postural drainage or Flutter device in conjunction with breathing and coughing compared to breathing and coughing alone in improving secretion removal and lung function in patients with acute exacerbation of bronchiectasis: A pilot study. Hong Kong Physiotherapy Journal 21:29-36.

van der Schans CP 2007 Conventional Chest Physical Therapy for Obstructive Lung Disease. Respiratory Care 52:1198 - 1209.

Venkategowda PM, Rao SM, Mutkule DP, Taggu AN 2014 Unexpected events occurring during the intra-hospital transport of critically ill ICU patients. Indian Journal of Critical Care Medicine 18: 354 - 357. 
Table 1: Criteria for assessing safety and effectiveness of ACTs

\begin{tabular}{|l|l|}
\hline Safety of ACT criteria: adverse reactions & Effectiveness of ACT criteria \\
\hline $\begin{array}{l}\text { Negative change in pulmonary function } \\
\text { tests }\end{array}$ & $\begin{array}{l}\text { Greater volume of sputum in a single } \\
\text { treatment session }\end{array}$ \\
\hline Deterioration in patient reported symptoms & $\begin{array}{l}\text { Reduction in sputum volume across the } \\
\text { course of treatment (e.g. 14 days of } \\
\text { antibiotics) }\end{array}$ \\
\hline $\begin{array}{l}\text { Decrease in blood oxygen levels measured } \\
\text { by arterial blood gas or pulse oximetry by } \\
\text { more than } 5 \% *\end{array}$ & $\begin{array}{l}\text { Positive change in blood oxygen levels } \\
\text { measured by arterial blood gases or pulse } \\
\text { oximetry }\end{array}$ \\
\hline & Improvement in patient reported symptoms \\
\hline & Improvement in HRQLL \\
\hline
\end{tabular}

Key: ACT; Airway clearance technique; HRQoL; Health related quality of life

*Venkategowda et al, 2001 
Table 2: Study Characteristics

\begin{tabular}{|c|c|c|c|c|c|c|c|c|c|}
\hline Study & Design & $\mathbf{N}$ & $\begin{array}{l}\text { Gender } \\
\text { M/F }\end{array}$ & $\begin{array}{l}\text { Age } \\
(\text { yrs) }\end{array}$ & $\begin{array}{l}\text { Baseline } \\
\text { FEV }_{1}\end{array}$ & $\begin{array}{l}\text { Baseline } \\
\text { difference } \\
\text { between } \\
\text { groups }\end{array}$ & Group 1 & Group 2 & Group 3 \\
\hline $\begin{array}{l}\text { D'Abrosca } \\
\text { et al. } \\
(2017)\end{array}$ & $\begin{array}{l}\text { Retrospective } \\
\text { cohort study }\end{array}$ & 28 & $13 / 15$ & $\begin{array}{l}41- \\
88\end{array}$ & $\begin{array}{l}\text { TPEP: } \\
1.00 \mathrm{~L} \\
(0.42) \\
\text { PEP: } 0.92 \\
\text { L }(0.37)\end{array}$ & $\begin{array}{l}\text { Nil significant } \\
\text { differences in } \\
\text { age, gender, } \\
\text { smoking } \\
\text { history, lung } \\
\text { function or } \\
\text { ABGs. }\end{array}$ & $\begin{array}{l}\text { Intervention: TPEP: } \\
\text { Blow through a } \\
\text { mouthpiece keeping } \\
\text { TPEP active as long as } \\
\text { possible on every } \\
\text { breath and cough as } \\
\text { needed or at least every } \\
\text { 3-5 minutes. } \\
\text { Two 15-minute sessions } \\
\text { daily. } \\
\text { Seated position with } \\
\text { elbows resting on hard } \\
\text { surface }\end{array}$ & $\begin{array}{l}\text { PEP mask: Instructed to } \\
\text { reach and maintain the } \\
\text { highest mid-expiratory } \\
\text { pressure tolerated } \\
\text { between } 10 \text { and } 20 \mathrm{~cm} \\
\mathrm{H}_{2} 0 \text { (measured by a } \\
\text { manometer weekly), } \\
\text { breathing at slightly } \\
\text { increased Vt, but not to } \\
\text { use force at the end of } \\
\text { the expiration. Approx. } \\
\text { every } 2 \text { minutes } \\
\text { instructed to perform a } \\
\text { FET manoeuvre; } \\
\text { huffing and/or coughing }\end{array}$ & NI \\
\hline
\end{tabular}




\begin{tabular}{|c|c|c|c|c|c|c|c|c|c|}
\hline & & & & & & & & $\begin{array}{l}\text { without the resistor. } \\
\text { Two } 15 \text {-minute sessions } \\
\text { daily. } \\
\text { Seated position with } \\
\text { elbows resting on a hard } \\
\text { surface }\end{array}$ & \\
\hline $\begin{array}{l}\text { AbdelHali } \\
\text { m et al. } \\
(2016)\end{array}$ & RCT & 30 & $20 / 10$ & $\begin{array}{l}52 \\
(15)\end{array}$ & $\begin{array}{l}\text { FEV } \mathbf{1} \% \\
\text { predicted } \\
\text { Interventio } \\
\text { n: } 57.2 \\
(13.8) \\
\text { Control: } \\
54.1(20.5)\end{array}$ & $\begin{array}{l}\text { No significant } \\
\text { differences in } \\
\text { any outcome at } \\
\text { baseline. } \\
\text { mmRC p = } \\
0.897 \\
\text { FVC p = } 0.986 \\
\text { FEV1 } p= \\
0.630\end{array}$ & $\begin{array}{l}\text { Intervention: ACBT } \\
\text { (breathing control, 2-3 } \\
\text { deep breaths, breathing } \\
\text { control, huff), cough as } \\
\text { required. } \\
\text { Each cycle lasted } \\
\text { approx. } 2 \text { minutes. } \\
\text { Repeated 15-20 minutes } \\
\text { with postural drainage } \\
\text { twice daily. }\end{array}$ & $\begin{array}{l}\text { Conventional chest } \\
\text { physiotherapy: } \\
\text { Use of postural drainage } \\
\text { positions with } \\
\text { diaphragmatic breathing } \\
\text { and percussion. } \\
\text { Positions not reported. } \\
\text { 15-20 minutes twice per } \\
\text { day. }\end{array}$ & $\mathrm{NI}$ \\
\hline
\end{tabular}




\begin{tabular}{|c|c|c|c|c|c|c|c|c|c|}
\hline & & & & & & $\begin{array}{l}\text { Sputum wet } \\
\text { volume } \mathrm{p}= \\
0.842 \\
\text { ABGs } \mathrm{p}= \\
0.140-0.330 \\
\text { Nil significant } \\
\text { difference in } \\
\text { age, height or } \\
\text { BMI }\end{array}$ & & & \\
\hline $\begin{array}{l}\text { Grillo et } \\
\text { al. (2015) }\end{array}$ & Cohort study & $\begin{array}{l}90 \\
(25 \\
\text { AEB } \\
)\end{array}$ & $11 / 18$ & $\begin{array}{l}63 \\
(12)\end{array}$ & NR & $\mathrm{N} / \mathrm{A}$ & $\begin{array}{l}\text { Assessed by a } \\
\text { physiotherapist at the } \\
\text { start of treatment and } \\
\text { prescribed an optimal } \\
\text { technique which was } \\
\text { completed until they } \\
\text { had } 2 \text { clear cycles or } \\
\text { until they fatigued. } \\
\text { Intervention: } \\
\text { Techniques included }\end{array}$ & NI & NI \\
\hline
\end{tabular}




\begin{tabular}{|c|c|c|c|c|c|c|c|c|c|}
\hline & & & & & & & $\begin{array}{l}\mathrm{ACBT}+/-\mathrm{PD} \text { and } \\
\text { autogenic drainage. }\end{array}$ & & \\
\hline $\begin{array}{l}\text { Patterson } \\
\text { et al. } \\
(2007)\end{array}$ & RCT & 20 & $10 / 10$ & $\begin{array}{l}61 \\
(10)\end{array}$ & $\begin{array}{l}\text { FEV } \mathbf{1} \% \\
\text { predicted } \\
\text { Mean } 64.7 \\
(21.1)\end{array}$ & $\begin{array}{l}\text { No differences } \\
\text { in baseline age } \\
\text { or lung } \\
\text { function } \\
\text { between } \\
\text { groups. }\end{array}$ & $\begin{array}{l}\text { 30-minute training } \\
\text { session on day one of } \\
\text { ABs with a } \\
\text { physiotherapist: } \\
2 \text { postural drainage } \\
\text { positions and } \\
\text { Acapella }{ }^{\circledR} \\
\text { Maximum } 15 \text { minutes } \\
\text { in each postural } \\
\text { drainage position. } \\
\text { Breathing control, } 10 \\
\text { breaths Acapella }{ }^{\circledR} \\
\text { inhaling to three-quarter } \\
\text { maximum breathing } \\
\text { capacity, 2-3 second } \\
\text { breath hold, active } \\
\text { exhalation to FRC, and }\end{array}$ & $\begin{array}{l}\text { 30-minute training } \\
\text { session on day } 1 \text { of oral } \\
\text { ABs with a } \\
\text { physiotherapist: } \\
\text { Review of their usual } \\
\text { ACT including } \\
\text { technique used, } \\
\text { positioning, duration } \\
\text { and frequency of } \\
\text { treatments. } \\
\text { "Usual" was defined as } \\
\text { the ACT currently used } \\
\text { by the patient (no } \\
\text { change made to their } \\
\text { ACT). } 90 \% \text { of } \\
\text { participants used } \\
\text { ACBT, } 10 \% \text { used PEP. }\end{array}$ & $\mathrm{NI}$ \\
\hline
\end{tabular}




\begin{tabular}{|c|c|c|c|c|c|c|c|c|c|}
\hline & & & & & & & $\begin{array}{l}\text { a cough or huff in a set } \\
\text { cycle. Completed twice } \\
\text { daily }\end{array}$ & $\begin{array}{l}\text { Most patients } \\
\text { completed the usual } \\
\text { ACT twice daily. }\end{array}$ & \\
\hline $\begin{array}{l}\text { Tsang and } \\
\text { Jones } \\
\text { (2003) }\end{array}$ & $\mathrm{RCT}$ & 15 & $8 / 7$ & $\begin{array}{l}67- \\
74 \\
(5- \\
15)\end{array}$ & $\begin{array}{l}\text { PD: } 0.78 \mathrm{~L} \\
(0.46) \\
\text { FL: } 0.62 \mathrm{~L} \\
(0.20) \\
\text { BC: } 0.56 \mathrm{~L} \\
(0.21)\end{array}$ & $\begin{array}{l}\text { Nil significant } \\
\text { differences } \\
\text { between the } \\
\text { three groups in } \\
\text { age, body } \\
\text { weight, height, } \\
\text { duration of } \\
\text { disease, and } \\
\text { amount of } \\
\text { sputum } \\
\text { produced or } \\
\text { spirometry in } \\
\text { first } 24 \text { hours } \\
\text { of } \\
\text { hospitalisation. }\end{array}$ & $\begin{array}{l}\text { PD: Adopt a maximum } \\
\text { of } 2 \text { gravity dependent } \\
\text { positions for drainage } \\
\text { of secretions for total } \\
\text { duration } 15 \text { mins. } \\
\text { During the } 15 \text {-minute } \\
\text { session, patients were } \\
\text { instructed to perform } \\
\text { BC every } 3 \text { minutes - } \\
\text { cycle of } 5 \text { slow deep } \\
\text { breaths then one } \\
\text { voluntary cough } \\
\text { followed by normal } \\
\text { relaxed breathing. }\end{array}$ & $\begin{array}{l}\text { FL: Taught the use of } \\
\text { Flutter }^{\circledR} \text { in a sitting } \\
\text { position for } 15 \text { minutes. } \\
\text { Cycle every } 3 \text { minutes } \\
\text { of } 5 \text { deep breaths } \\
\text { expired through the } \\
\text { Flutter }{ }^{\circledR} \text {, then one cough } \\
\text { followed by breathing } \\
\text { control. Completed } \\
3 x / \text { day from day } 2 \text { of } \\
\text { admission until DC }\end{array}$ & $\begin{array}{l}\text { BC: taught } \\
\text { to perform } \\
\text { cycle of } 5 \\
\text { deep } \\
\text { breaths } \\
\text { followed by } \\
\text { a cough } \\
\text { and } \\
\text { breathing } \\
\text { control } \\
\text { every } 3 \\
\text { mins for } 15 \\
\text { mins. } \\
\text { Seated } \\
\text { position. } \\
\text { Completed } \\
3 x / \text { day } \\
\text { from day } 2\end{array}$ \\
\hline
\end{tabular}




\begin{tabular}{|c|c|c|c|c|c|c|c|c|c|}
\hline & & & & & & & $\begin{array}{l}\text { Completed 3x/day from } \\
\text { day } 2 \text { of admission until } \\
\text { DC home. }\end{array}$ & & $\begin{array}{l}\text { of } \\
\text { admission } \\
\text { until DC. }\end{array}$ \\
\hline $\begin{array}{l}\text { Herala and } \\
\text { Gislason } \\
(1988)\end{array}$ & $\mathrm{RCT}$ & $\begin{array}{l}15 \\
(2 \\
\text { AEB } \\
)\end{array}$ & $0 / 2$ & $\begin{array}{l}50 \text { to } \\
72 \\
\text { year } \\
\text { s }\end{array}$ & NR & $\mathrm{N} / \mathrm{A}$ & $\begin{array}{l}\text { Thoracic Compression } \\
\text { (TC): physiotherapist } \\
\text { placed hands on lower } \\
\text { part of thorax and } \\
\text { manually compressed } \\
\text { the thorax during the } \\
\text { end of the exhalation. } \\
\text { Completed } 30 \text { times at a } \\
\text { comfortable rate in a } \\
\text { sitting position. }\end{array}$ & $\begin{array}{l}\text { PEP - patients } \\
\text { instructed to inhale and } \\
\text { then to expire smoothly, } \\
\text { without force through a } \\
\text { plastic tube - the end of } \\
\text { which was placed in a } \\
\text { bottle containing } 10 \mathrm{~cm} \\
\text { of water. Completed } 30 \\
\text { times at a comfortable } \\
\text { rate in a sitting position. }\end{array}$ & \\
\hline
\end{tabular}

Data are presented as mean (SD) of group as a whole or range of means (SD) if presented in multiple groups unless otherwise stated.

Key: ABs: Antibiotics; ACBT: Active cycle of breathing technique; ACT; Airway clearance technique; AEB: Acute exacerbation of bronchiectasis; BC: Breathing and coughing; DC; Discharge; FET: Forced expiration technique; FL: Flutter ${ }^{\circledR}$ valve; FRC: Functional residual capacity; N/A: Not applicable; NI: Not included; NR: Not reported; PEP: Positive expiratory pressure; PD: Postural drainage; RCT: Randomised controlled trial; RXT: Crossover trial; TPEP: Temporary positive expiratory pressure; Vt: Tidal volume. 


\section{Table 3: Final quality assessment results}

\begin{tabular}{|c|c|c|c|c|c|c|c|c|c|c|c|c|c|c|c|c|c|c|c|c|c|c|c|c|c|c|c|c|c|c|}
\hline \multirow[t]{2}{*}{ Studies $=6$} & & & \multicolumn{27}{|c|}{ Scores according to the modified* Downs and Black (1998) checklist } & \multirow{2}{*}{$\begin{array}{l}\text { Quality } \\
\text { Rating }\end{array}$} \\
\hline & 1 & 2 & 3 & 4 & 5 & 6 & 7 & 8 & 9 & 10 & 11 & 12 & 13 & 14 & 15 & 16 & 17 & 18 & 19 & 20 & 21 & 22 & & & 4 & 25 & 26 & 27 & Total & \\
\hline $\begin{array}{l}\text { D'Abrosca } \\
\text { et al. (2017) }\end{array}$ & 1 & 1 & 1 & 1 & 1 & 1 & 1 & 1 & 1 & 1 & 1 & 0 & 0 & 0 & 0 & 0 & 0 & 1 & 0 & 1 & 1 & 1 & 0 & & & 0 & 0 & 0 & 15 & Moderate \\
\hline $\begin{array}{l}\text { AbdelHalim } \\
\text { et al. (2016) }\end{array}$ & 1 & 1 & 1 & 1 & 1 & 1 & 0 & 1 & 1 & 1 & 0 & 0 & 1 & 0 & 0 & 1 & 1 & 1 & 0 & 1 & 1 & 1 & 1 & & & 1 & 1 & 0 & 19 & Moderate \\
\hline $\begin{array}{l}\text { Grillo et al. } \\
(2015)\end{array}$ & 1 & 1 & 1 & 0 & 0 & 1 & 1 & 1 & 0 & 0 & 0 & 0 & 0 & 0 & 0 & 1 & 1 & 1 & 1 & 1 & 1 & 1 & 0 & & & 1 & 1 & 0 & 15 & Moderate \\
\hline $\begin{array}{l}\text { Patterson et } \\
\text { al. }(2007)\end{array}$ & 1 & 1 & 1 & 1 & 1 & 1 & 1 & 1 & 1 & 1 & 1 & 1 & 1 & 0 & 1 & 1 & 1 & 1 & 1 & 1 & 1 & 1 & 1 & & & 0 & 1 & 1 & 24 & Strong \\
\hline $\begin{array}{l}\text { Tsang and } \\
\text { Jones } \\
(2003)\end{array}$ & 1 & 1 & 1 & 1 & 1 & 1 & 1 & 1 & 1 & 1 & 0 & 0 & 1 & 0 & 0 & 1 & 1 & 1 & 1 & 1 & 1 & 1 & 1 & & & 1 & 1 & 0 & 21 & Strong \\
\hline $\begin{array}{l}\text { Herala and } \\
\text { Gislason } \\
(1988)\end{array}$ & 1 & 1 & 1 & 1 & 1 & 1 & 1 & 0 & 1 & 0 & 0 & 0 & 0 & 0 & 0 & 1 & 1 & 0 & 0 & 1 & 1 & 1 & 0 & & & 0 & 1 & 0 & 14 & Moderate \\
\hline
\end{tabular}

Note: These are the final quality assessment scores yielded from assessment by two authors. Scores of $1=$ Yes, $0=$ No or unable to determine were used for each criterion. *A modified version was implemented, where question 5 and question 27 were each scored dichotomously. 


\section{Table 4: Summary of key findings}

\begin{tabular}{|c|c|c|c|}
\hline Study & Duration & Outcome measures and timing & Summary of findings \\
\hline D'Abrosca et al. (2017) & $\begin{array}{l}\text { Retrospective } \\
\text { data from } 4 \text { years. } \\
\text { Patients admitted } \\
\text { for a minimum of } \\
10 \text { days. }\end{array}$ & $\begin{array}{l}\text { Spirometry } \\
\text { Arterial Blood gases } \\
\text { All completed on admission and } \\
\text { DC }\end{array}$ & $\begin{array}{l}\text { No significant difference between TPEP and PEP groups } \\
\text { in spirometry }\left(\mathrm{FVC} \mathrm{p}=0.792, \mathrm{FEV}_{1} \mathrm{p}=0.841\right) \text { or } \\
\text { arterial blood gases }\left(\mathrm{pH} p=0.313, \mathrm{HCO}_{3} \mathrm{p}=0.290, \mathrm{PO}_{2}\right. \\
\mathrm{p}=0.244, \mathrm{PCO} 2 \mathrm{p}=0.734) \text {. }\end{array}$ \\
\hline $\begin{array}{l}\text { AbdelHalim et al. } \\
\text { (2016) }\end{array}$ & 14 days & $\begin{array}{l}\text { HRQoL - LCQ } \\
\text { Dyspnoea - mMRC } \\
\text { Spirometry } \\
\text { Arterial blood gases } \\
\text { Sputum collection (wet weight) } \\
\text { daily } \\
\text { All OCMs completed on admission } \\
\text { and day } 14\end{array}$ & $\begin{array}{l}\text { Between groups differences: } \\
\text { ACBT superior to control treatment in post } \\
\text { physiotherapy outcome measures, as follows: } \\
\text { - } \mathrm{PaO}_{2}(\mathrm{p}=0.043) \\
\text { - } \mathrm{P}(\mathrm{A}-\mathrm{a}) \mathrm{O}_{2} \text { gradient }(\mathrm{p}=0.014) \\
\text { - } \quad \text { LCQ physical score }(\mathrm{p}=0.023) \\
\text { - LCQ total score }(\mathrm{p}=0.019) \\
\text { - Sputum volume }(\mathrm{p}=0.023)\end{array}$ \\
\hline
\end{tabular}




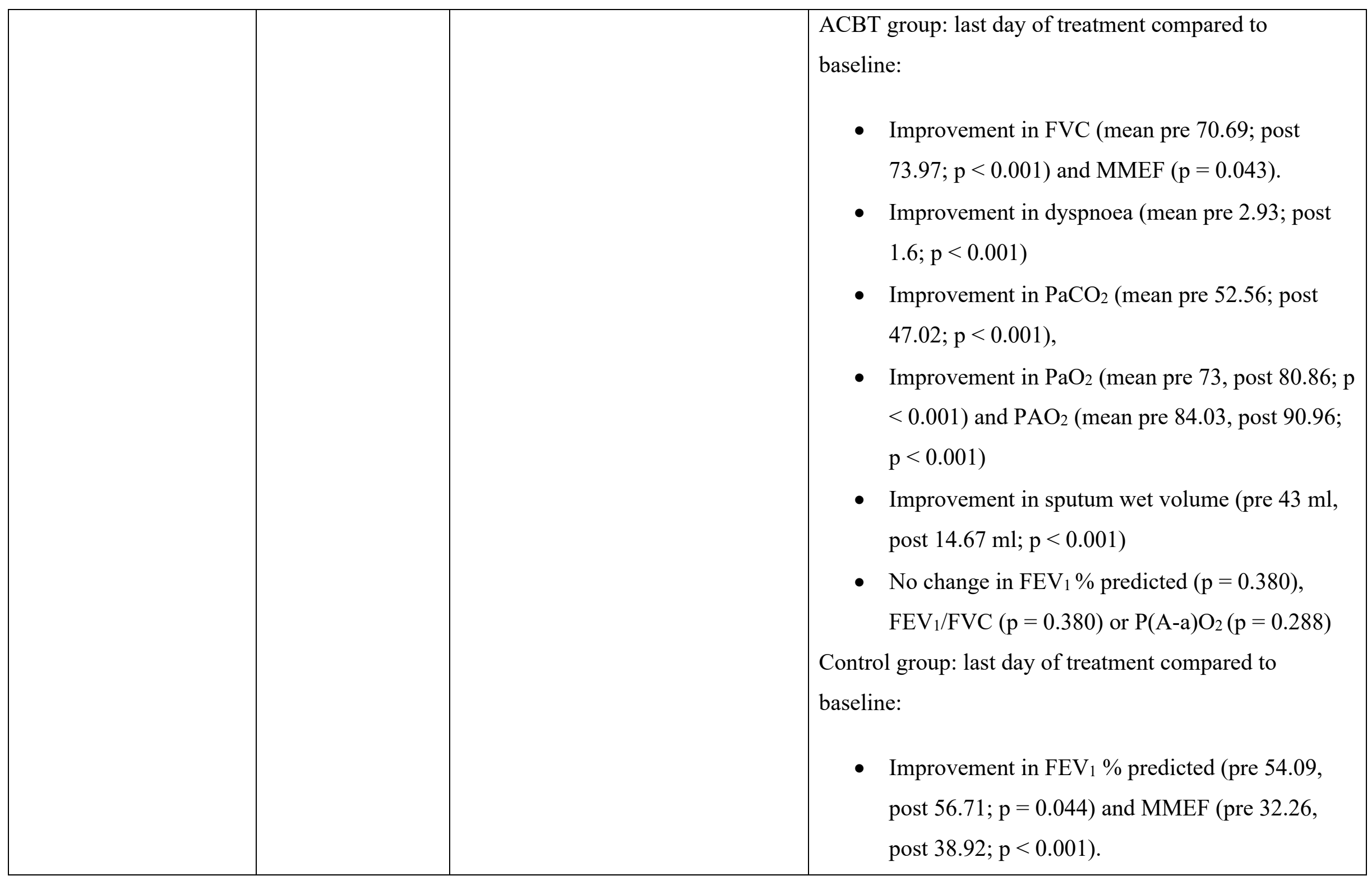




\begin{tabular}{|c|c|c|c|}
\hline & & & 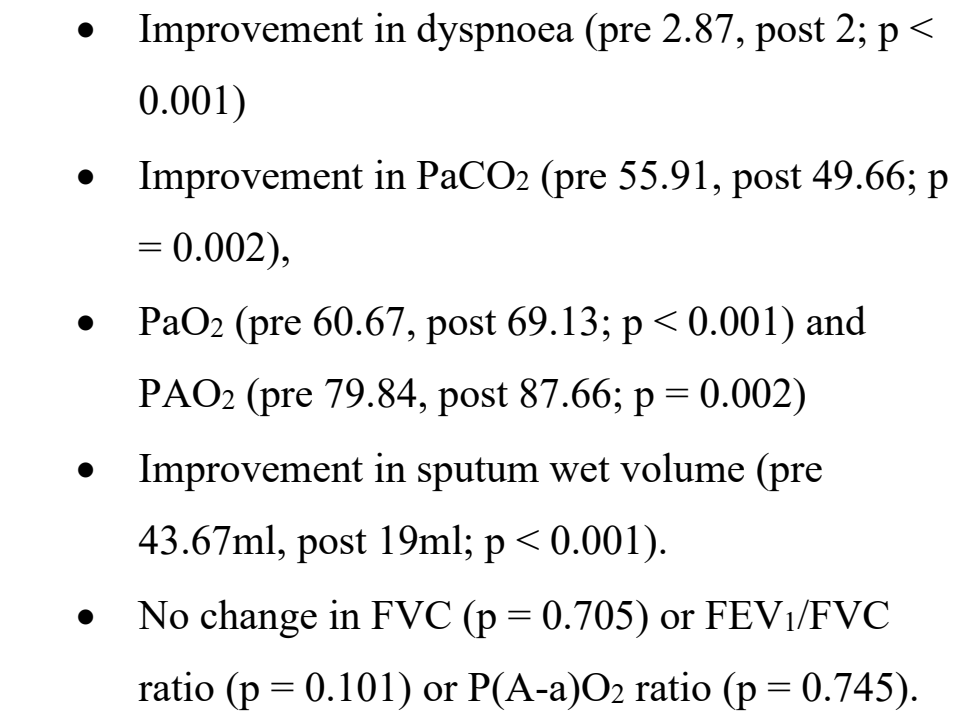 \\
\hline Grillo et al. (2015) & NR & $\begin{array}{l}\text { Lung clearance index (LCI). } \\
\text { Spirometry } \\
\text { Completed on two occasions: visit } \\
1 \text { within } 48 \text { hrs of admission; pre } \\
\text { and post physiotherapy; and on } \\
\text { reaching clinical recovery at DC as } \\
\text { determined by a consultant pre and } \\
\text { post physiotherapy }\end{array}$ & $\begin{array}{l}\text { No change in LCI from pre- to post-physiotherapy at } \\
\text { visit } 1 \text { or on day of discharge (start exacerbation } \mathrm{p}= \\
0.505 \text {; end exacerbation } \mathrm{p}=0.491 \text { ). } \\
\text { Actual change in lung function tests not reported, all } \\
\text { changes reported as z scores only. Small but significant } \\
\text { change in FEV } 1 \text { z score following physiotherapy at start } \\
\text { and end exacerbation (start exacerbation } \mathrm{p}=0.012 \text {; end } \\
\text { exacerbation } \mathrm{p}=0.037 \text { ). }\end{array}$ \\
\hline
\end{tabular}




\begin{tabular}{|c|c|c|c|}
\hline Patterson et al. (2007) & $\begin{array}{l}\text { 10-14 days } \\
\text { (duration of oral } \\
\text { antibiotics) }\end{array}$ & $\begin{array}{l}\text { Spirometry } \\
\text { Pulse oximetry } \\
\text { Borg breathlessness scale } \\
\text { (dyspnoea) } \\
15 \text { count breathlessness score } \\
\text { Questionnaire regarding patient's } \\
\text { perceived changes in sputum, } \\
\text { cough and other symptoms. } \\
\text { Number of coughs during session } \\
\text { Completed pre and post ACT } \\
\text { session day } 1 \text { and final day of oral } \\
\text { ABs (day 10-14). }\end{array}$ & 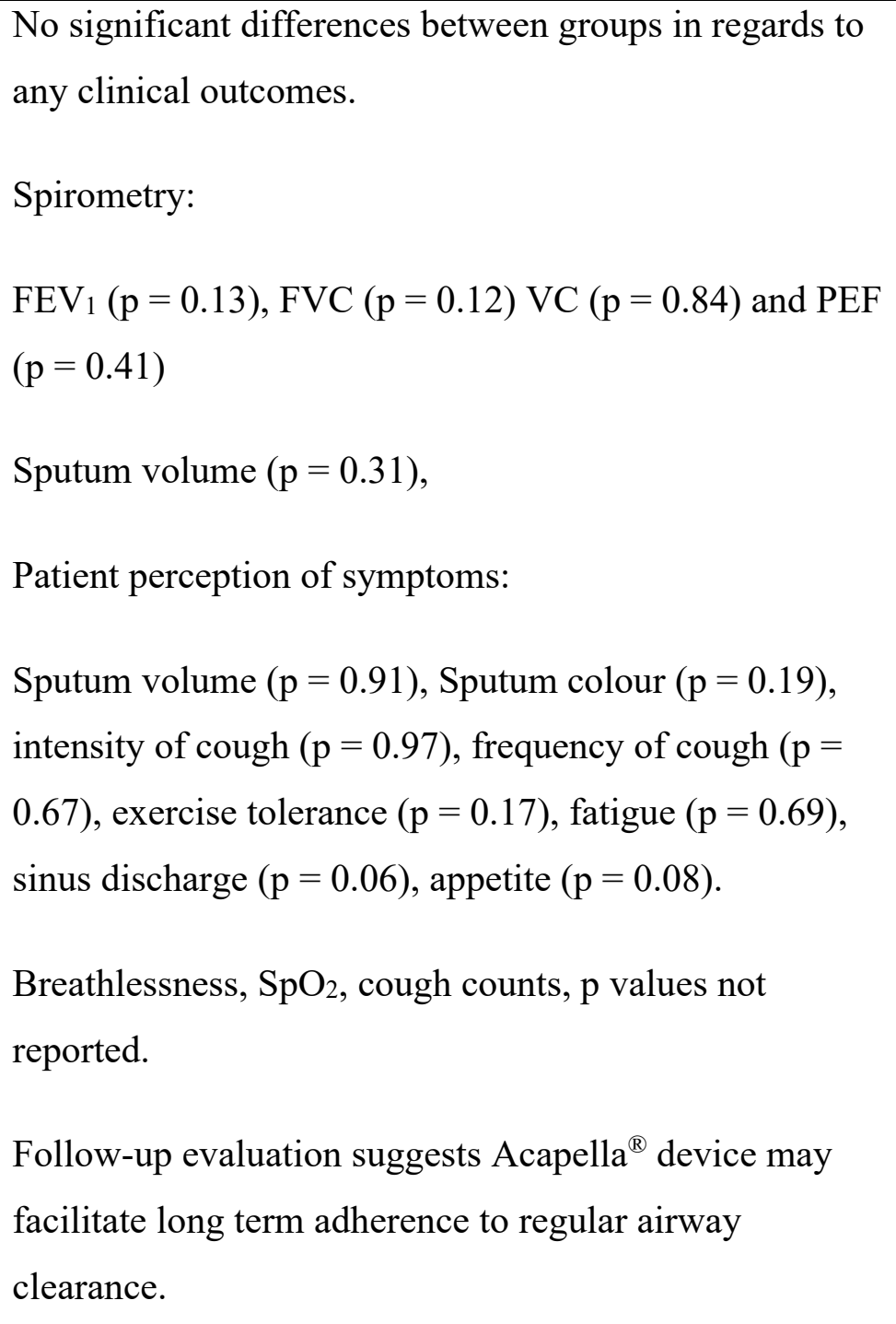 \\
\hline
\end{tabular}




\begin{tabular}{|c|c|c|c|}
\hline Tsang and Jones (2003) & $\begin{array}{l}\text { From day } 2 \text { of } \\
\text { admission until } \\
\text { DC } \\
\text { PD: } 7 \text { days }(3.3) \\
\text { FL: } 6 \text { days (3.83) } \\
\text { BC: } 5 \text { days }(0.84)\end{array}$ & $\begin{array}{l}\text { Lung function assessed on day } 1 \\
\text { (before treatment) and then before } \\
\text { and after each treatment session on } \\
\text { days } 2,4 \text { and day of DC. } \\
\text { Wet weight of sputum: } \\
\text { expectorated during the } 15 \text {-minute } \\
\text { session (S15), during the } 15 \text { mins } \\
\text { after treatment (S30) and at } 24 \\
\text { hours (S24) - all recorded days } 2 \\
\text { and } 4 \text { and day of DC. } \\
\text { HR and } \mathrm{O}_{2} \text { saturations of patient } \\
\text { monitored during each treatment. } \\
\text { Patient questionnaire each session } \\
\text { regarding perceived effectiveness } \\
\text { and ease of application. }\end{array}$ & 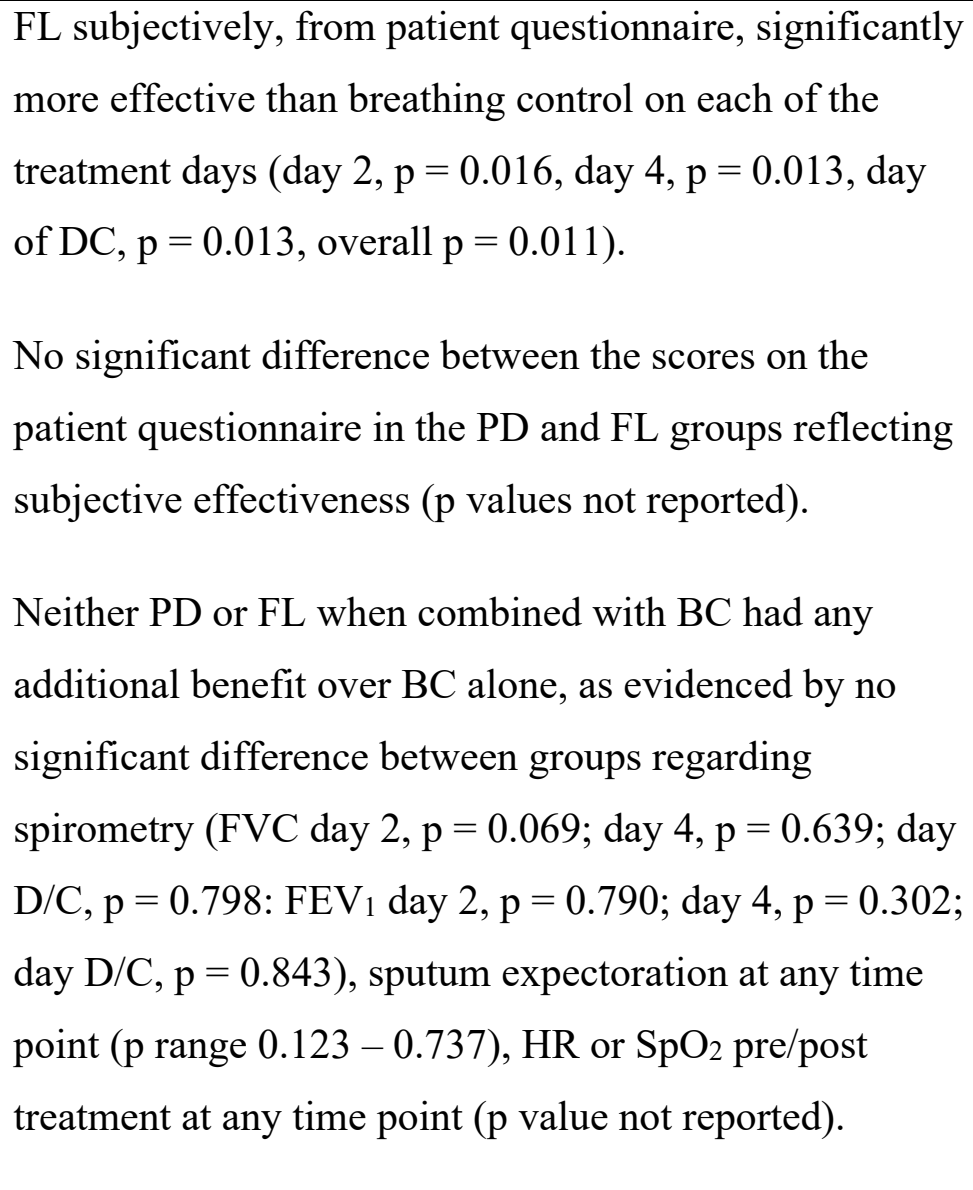 \\
\hline $\begin{array}{l}\text { Herala and Gislason } \\
\text { (1988) }\end{array}$ & $\begin{array}{l}2 \text { days }- \text { single } \\
\text { treatment session } \\
\text { each day. }\end{array}$ & $\begin{array}{l}\text { Transcutaneous partial pressure of } \\
\mathrm{PCO}_{2} \text { and } \mathrm{PO}_{2} \text {. Two electrodes } \\
\text { attached with plastic mounting } \\
\text { rings to the skin of the upper }\end{array}$ & $\begin{array}{l}\text { Small brief decrease in transcutaneous pressure of } \mathrm{PCO}_{2} \\
\text { and small increase in transcutaneous pressure of } \mathrm{PO}_{2} \text { in }\end{array}$ \\
\hline
\end{tabular}




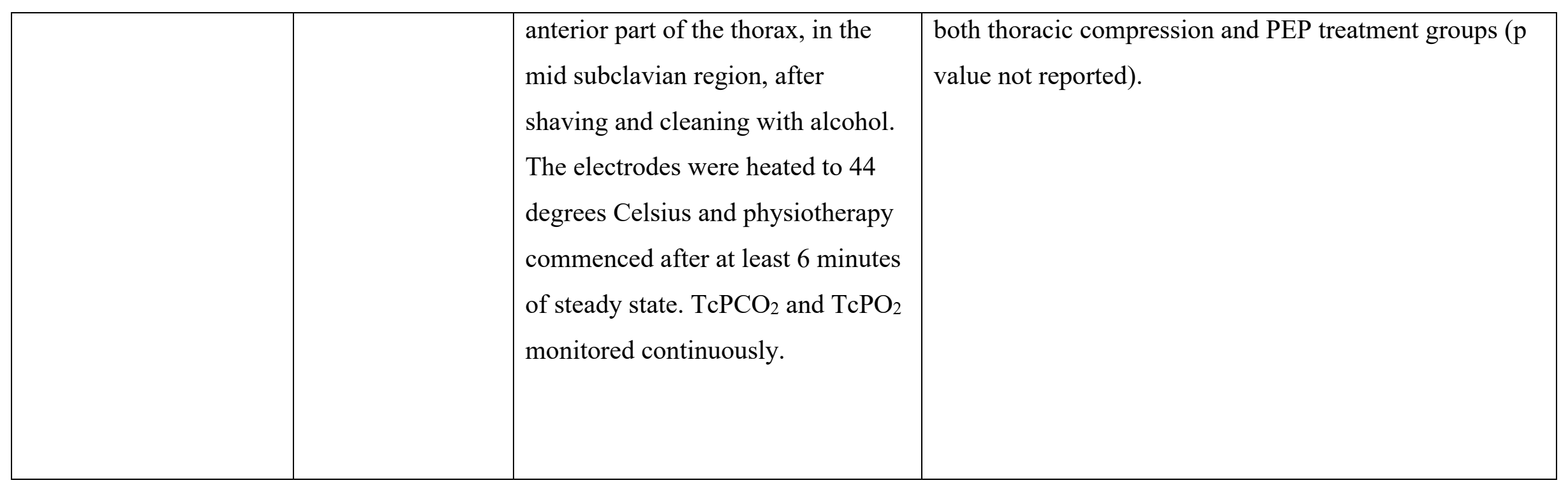

Key: ABs: Antibiotics; ACBT: Active cycle of breathing technique; BC: Breathing and coughing; DC; Discharge; FEV1: Forced expiratory volume in 1 second \% predicted; FL: Flutter ${ }^{\circledR}$ valve; FVC: Functional vital capacity (litres); HR: Heart Rate; HRQoL: Health related quality of life; LCI: Lung clearance index; LCQ: Leister Cough Questionnaire; MMEF: maximal mid-expiratory flow; mMRC: modified Medical Research Council; NR: Not reported; OCM: Outcome measures; $\mathrm{PaO}_{2}$ : Partial pressure of Oxygen ( $\mathrm{mmHg}$ ); $\mathrm{PaCO}_{2}$ : Partial pressure of Carbon dioxide $(\mathrm{mmHg}) ; \mathrm{PAO}_{2}$ : Partial pressure of alveolar oxygen ( $\mathrm{mmHg}$ ); PEP: Positive expiratory pressure; PD: Postural drainage; SpO $2:$ pulse oximetry level (\% haemoglobin saturated with oxygen); $\mathrm{TcPCO}_{2}$ : Transcutaneous pressure of carbon dioxide (kPa); $\mathrm{TcPO}_{2}$ : transcutaneous pressure of Oxygen (kPa); TPEP: Temporary positive expiratory pressure. 


\section{Appendix 1:}

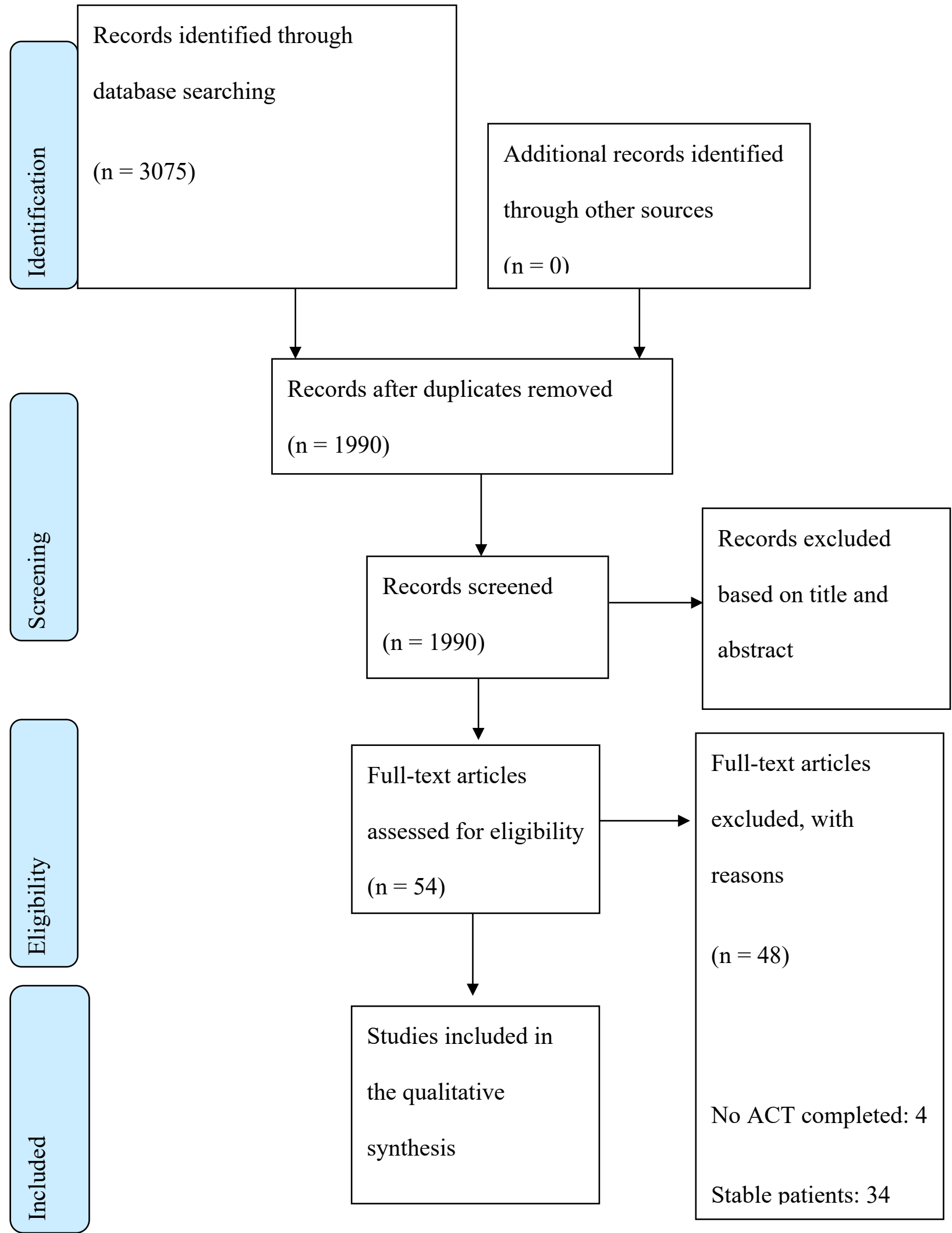

Figure 1: PRISMA flow diagram depicting results of literature search and selection processes (CINAHL: Cumulative Index of Nursing and Allied Health Literature; PEDro: Physiotherapy Evidence Database) 


\section{Appendix 2:}

Search completed in PubMed:

Bronchiectasis OR “primary ciliary dyskinesia” OR “young syndrome” OR "kartageners syndrome” OR "non CF bronchiectasis"

AND

"respiratory therapy" OR "airway clearance" OR "airway clearance techniques" OR "airway clearance therapy" OR "chest physiotherapy" OR "chest physical therapy” OR "physical therapy" OR "mucociliary clearance" OR "bronchopulmonary hygiene” OR "tracheobronchial clearance" OR "active cycle" OR ACBT OR "deep breathing exercise" or DBE OR "thoracic expansion" OR TEE OR “postural drainage” OR “gravity-assisted drainage” OR “autogenic drainage” OR GAD OR FET OR “forced expiratory technique” OR huff* OR PEP OR PEEP OR “positive expiratory pressure” OR "hi PEP” OR "bubblePEP” OR “bottle-PEP” OR oscillat* OR “mouthpiece PEP” OR “pari-PEP” OR VRP1 OR flutter* OR desitin OR cornet OR acapella OR scandipharm OR percuss* OR vibrat* OR vest OR HFCWO OR OHFO

PubMed MeSH Terms

"Bronchiectasis"[MeSH]

"Kartagener Syndrome"[MeSH] 
"Ciliary Motility Disorders"[MeSH]

"Young Syndrome" [Supplementary Concept]

AND

"Physical Therapy Modalities"[MeSH]

"Mucociliary Clearance"[MeSH]

"Respiratory Therapy"[MeSH] 


\section{Appendix 3:}

Modified Downs and Black checklist used to determine methodological quality of included studies.

\begin{tabular}{|c|c|c|}
\hline Item & Criteria & Possible Answers \\
\hline \multicolumn{3}{|c|}{ Reporting } \\
\hline 1 & Is the hypothesis/aim/objective of the study clearly described? & $\begin{array}{l}\text { Yes }=1 \\
\text { No }=0\end{array}$ \\
\hline 2 & $\begin{array}{l}\text { Are the main outcomes to be measured clearly described in the } \\
\text { Introduction or Methods section? If the main outcomes are first } \\
\text { mentioned in the Results section, the question should be } \\
\text { answered no. }\end{array}$ & $\begin{array}{l}\text { Yes }=1 \\
\text { No }=0\end{array}$ \\
\hline 3 & $\begin{array}{l}\text { Are the characteristics of the patients included in the study } \\
\text { clearly described? In cohort studies and trials, inclusion and/or } \\
\text { exclusion criteria should be given. In case-control studies, a } \\
\text { case-definition and the source for controls should be given. }\end{array}$ & $\begin{array}{l}\text { Yes }=1 \\
\text { No }=0\end{array}$ \\
\hline 4 & $\begin{array}{l}\text { Are the interventions of interest clearly described? Treatments } \\
\text { and placebo (where relevant) that are to be compared should be } \\
\text { clearly described. }\end{array}$ & $\begin{array}{l}\text { Yes }=1 \\
\text { No }=0\end{array}$ \\
\hline 5 & $\begin{array}{l}\text { Are the distributions of principal confounders in each group of } \\
\text { subjects to be compared clearly described? A list of principal } \\
\text { confounders is provided. }\end{array}$ & $\begin{array}{l}\text { Yes }=1 \\
\text { No }=0\end{array}$ \\
\hline 6 & $\begin{array}{l}\text { Are the main findings of the study clearly described? Simple } \\
\text { outcome data (including denominators and numerators) should } \\
\text { be reported for all major findings so that the reader can check the } \\
\text { major analyses and conclusions. (This question does not cover } \\
\text { statistical tests which are considered below). }\end{array}$ & $\begin{array}{l}\text { Yes }=1 \\
\text { No }=0\end{array}$ \\
\hline
\end{tabular}




\begin{tabular}{|c|c|c|}
\hline 7 & $\begin{array}{l}\text { Does the study provide estimates of the random variability in the } \\
\text { data for the main outcomes? In non-normally distributed data the } \\
\text { interquartile range of results should be reported. In normally } \\
\text { distributed data the standard error, standard deviation or } \\
\text { confidence intervals should be reported. If the distribution of the } \\
\text { data is not described, it must be assumed that the estimates used } \\
\text { were appropriate and the question should be answered yes. }\end{array}$ & $\begin{array}{l}\text { Yes }=1 \\
\text { No }=0\end{array}$ \\
\hline 8 & $\begin{array}{l}\text { Have all important adverse events that may be a consequence of } \\
\text { the intervention been reported? This should be answered yes if } \\
\text { the study demonstrates that there was a comprehensive attempt } \\
\text { to measure adverse events. (A list of possible adverse events is } \\
\text { provided). }\end{array}$ & $\begin{array}{l}\text { Yes }=1 \\
\text { No }=0\end{array}$ \\
\hline 9 & $\begin{array}{l}\text { Have the characteristics of patients lost to follow-up been } \\
\text { described? This should be answered yes where there were no } \\
\text { losses to follow-up or where losses to follow-up were so small } \\
\text { that findings would be unaffected by their inclusion. This should } \\
\text { be answered no where a study does not report the number of } \\
\text { patients lost to follow-up. }\end{array}$ & $\begin{array}{l}\text { Yes }=1 \\
\text { No }=0\end{array}$ \\
\hline 10 & $\begin{array}{l}\text { Have actual probability values been reported (e.g. } 0.035 \text { rather } \\
\text { than }<0.05 \text { ) for the main outcomes except where the probability } \\
\text { value is less than } 0.001 \text { ? }\end{array}$ & $\begin{array}{l}\text { Yes }=1 \\
\text { No }=0\end{array}$ \\
\hline \multicolumn{3}{|c|}{ External validity } \\
\hline 11 & $\begin{array}{l}\text { Were the subjects asked to participate in the study representative } \\
\text { of the entire population from which they were recruited? The } \\
\text { study must identify the source population for patients and } \\
\text { describe how the patients were selected. Patients would be } \\
\text { representative if they comprised the entire source population, an } \\
\text { unselected sample of consecutive patients, or a random sample. } \\
\text { Random sampling is only feasible where a list of all members of } \\
\text { the relevant population exists. Where a study does not report the } \\
\text { proportion of the source population from which the patients are } \\
\text { derived, the question should be answered as unable to determine. }\end{array}$ & $\begin{array}{l} \\
\text { Yes }=1 \\
\text { No }=0 \\
\text { Unable to determine }= \\
0 \\
\end{array}$ \\
\hline
\end{tabular}




\begin{tabular}{|c|c|c|}
\hline 12 & $\begin{array}{l}\text { Were those subjects who were prepared to participate } \\
\text { representative of the entire population from which they were } \\
\text { recruited? The proportion of those asked who agreed should be } \\
\text { stated. Validation that the sample was representative would } \\
\text { include demonstrating that the distribution of the main } \\
\text { confounding factors was the same in the study sample and the } \\
\text { source population. }\end{array}$ & $\begin{array}{l}\text { Yes }=1 \\
\text { No }=0 \\
\text { Unable to determine }= \\
0\end{array}$ \\
\hline 13 & $\begin{array}{l}\text { Were the staff, places, and facilities where the patients were } \\
\text { treated, representative of the treatment the majority of patients } \\
\text { receive? For the question to be answered yes the study should } \\
\text { demonstrate that the intervention was representative of that in } \\
\text { use in the source population. The question should be answered } \\
\text { no if, for example, the intervention was undertaken in a } \\
\text { specialist centre unrepresentative of the hospitals most of the } \\
\text { source population would attend. }\end{array}$ & $\begin{array}{l}\text { Yes }=1 \\
\text { No }=0 \\
\text { Unable to determine }= \\
0\end{array}$ \\
\hline \multicolumn{3}{|c|}{ Internal validity - bias } \\
\hline 14 & $\begin{array}{l}\text { Was an attempt made to blind study subjects to the intervention } \\
\text { they have received? For studies where the patients would have } \\
\text { no way of knowing which intervention they received, this should } \\
\text { be answered yes. }\end{array}$ & $\begin{array}{l}\text { Yes }=1 \\
\text { No }=0 \\
\text { Unable to determine }= \\
0\end{array}$ \\
\hline 15 & $\begin{array}{l}\text { Was an attempt made to blind those measuring the main } \\
\text { outcomes of the intervention? }\end{array}$ & $\begin{array}{l}\text { Yes }=1 \\
\text { No }=0 \\
\text { Unable to determine }= \\
0\end{array}$ \\
\hline 16 & $\begin{array}{l}\text { If any of the results of the study were based on "data dredging", } \\
\text { was this made clear? Any analyses that had not been planned at } \\
\text { the outset of the study should be clearly indicated. If no } \\
\text { retrospective unplanned subgroup analyses were reported, then } \\
\text { answer yes. }\end{array}$ & $\begin{array}{l}\text { Yes }=1 \\
\text { No }=0 \\
\text { Unable to determine }= \\
0\end{array}$ \\
\hline 17 & $\begin{array}{l}\text { In trials and cohort studies, do the analyses adjust for different } \\
\text { lengths of follow-up of patients, or in case-control studies, is the } \\
\text { time period between the intervention and outcome the same for } \\
\text { cases and controls? Where follow-up was the same for all study } \\
\text { patients the answer should be yes. If different lengths of follow- } \\
\text { up were adjusted for by, for example, survival analysis the } \\
\text { answer should be yes. Studies where differences in follow-up are } \\
\text { ignored should be answered no. }\end{array}$ & $\begin{array}{l}\text { Yes }=1 \\
\text { No }=0 \\
\text { Unable to determine }= \\
0\end{array}$ \\
\hline
\end{tabular}




\begin{tabular}{|c|c|c|}
\hline 18 & $\begin{array}{l}\text { Were the statistical tests used to assess the main outcomes } \\
\text { appropriate? The statistical techniques used must be appropriate } \\
\text { to the data. For example, nonparametric methods should be used } \\
\text { for small sample sizes. Where little statistical analysis has been } \\
\text { undertaken but where there is no evidence of bias, the question } \\
\text { should be answered yes. If the distribution of the data (normal or } \\
\text { not) is not described it must be assumed that the estimates used } \\
\text { were appropriate and the question should be answered yes. }\end{array}$ & $\begin{array}{l} \\
\text { Yes }=1 \\
\text { No }=0 \\
\text { Unable to determine }= \\
0\end{array}$ \\
\hline 19 & $\begin{array}{l}\text { Was compliance with the intervention/s reliable? Where there } \\
\text { was non- compliance with the allocated treatment or where there } \\
\text { was contamination of one group, the question should be } \\
\text { answered no. For studies where the effect of any } \\
\text { misclassification was likely to bias any association to the null, } \\
\text { the question should be answered yes. }\end{array}$ & $\begin{array}{l}\text { Yes }=1 \\
\text { No }=0 \\
\text { Unable to determine }= \\
0\end{array}$ \\
\hline 20 & $\begin{array}{l}\text { Were the main outcome measures used accurate (valid and } \\
\text { reliable)? For studies where the outcome measures are clearly } \\
\text { described, the question should be answered yes. For studies } \\
\text { which refer to other work or that demonstrates the outcome } \\
\text { measures are accurate, the question should be answered as yes. }\end{array}$ & $\begin{array}{l}\text { Yes }=1 \\
\text { No }=0 \\
\text { Unable to determine }= \\
0\end{array}$ \\
\hline \multicolumn{3}{|c|}{ Internal validity - confounding (selection bias) } \\
\hline 21 & $\begin{array}{l}\text { Were the patients in different intervention groups (trials and } \\
\text { cohort studies) or were the cases and controls (case-control } \\
\text { studies) recruited from the same population? For example, } \\
\text { patients for all comparison groups should be selected from the } \\
\text { same hospital. The question should be answered unable to } \\
\text { determine for cohort and case-control studies where there is no } \\
\text { information concerning the source of patients included in the } \\
\text { study. }\end{array}$ & $\begin{array}{l}\text { Yes }=1 \\
\text { No }=0 \\
\text { Unable to determine }= \\
0\end{array}$ \\
\hline 22 & $\begin{array}{l}\text { Were study subjects in different intervention groups (trials and } \\
\text { cohort studies) or were the cases and controls (case-control } \\
\text { studies) recruited over the same period of time? For a study } \\
\text { which does not specify the time period over which patients were } \\
\text { recruited, the question should be answered as unable to } \\
\text { determine. }\end{array}$ & $\begin{array}{l}\text { Yes }=1 \\
\text { No }=0 \\
\text { Unable to determine }= \\
0\end{array}$ \\
\hline 23 & $\begin{array}{l}\text { Were study subjects randomized to intervention groups? Studies } \\
\text { which state that subjects were randomized should be answered } \\
\text { yes except where method of randomization would not ensure } \\
\text { random allocation. For example alternate allocation would score } \\
\text { no because it is predictable. }\end{array}$ & $\begin{array}{l}\text { Yes }=1 \\
\text { No }=0 \\
\text { Unable to determine }= \\
0\end{array}$ \\
\hline
\end{tabular}




\begin{tabular}{|c|c|c|}
\hline 24 & $\begin{array}{l}\text { Was the randomized intervention assignment concealed from } \\
\text { both patients and health care staff until recruitment was } \\
\text { complete and irrevocable? All non- randomized studies should } \\
\text { be answered no. If assignment was concealed from patients but } \\
\text { not from staff, it should be answered no. }\end{array}$ & $\begin{array}{l}\text { Yes }=1 \\
\text { No }=0 \\
\text { Unable to determine }= \\
0\end{array}$ \\
\hline 25 & $\begin{array}{l}\text { Was there adequate adjustment for confounding in the analyses } \\
\text { from which the main findings were drawn? This question should } \\
\text { be answered no for trials if: the main conclusions of the study } \\
\text { were based on analyses of treatment rather than intention to } \\
\text { treat; the distribution of known confounders in the different } \\
\text { treatment groups was not described; or the distribution of known } \\
\text { confounders differed between the treatment groups but was not } \\
\text { taken into account in the analyses. In non-randomized studies if } \\
\text { the effect of the main confounders was not investigated or } \\
\text { confounding was demonstrated but no adjustment was made in } \\
\text { the final analyses the question should be answered as no. }\end{array}$ & $\begin{array}{l} \\
\text { Yes }=1 \\
\text { No }=0 \\
\text { Unable to determine }= \\
0 \\
\\
\end{array}$ \\
\hline 26 & $\begin{array}{l}\text { Were losses of patients to follow-up taken into account? If the } \\
\text { numbers of patients lost to follow-up are not reported, the } \\
\text { question should be answered as unable to determine. If the } \\
\text { proportion lost to follow-up was too small to affect the main } \\
\text { findings, the question should be answered yes. }\end{array}$ & $\begin{array}{l}\text { Yes }=1 \\
\text { No }=0 \\
\text { Unable to determine }= \\
0\end{array}$ \\
\hline \multicolumn{3}{|c|}{ Power } \\
\hline $27 *$ & $\begin{array}{l}\text { Did the study provide sample size calculations to determine } \\
\text { appropriate power? }\end{array}$ & $\begin{array}{l}\text { Yes }=1 \\
\text { No }=0\end{array}$ \\
\hline
\end{tabular}

